Insight, part of a Special Feature on Reconciling Art and Science for Sustainability

\title{
Sonifying social-ecological change: A wetland laments agricultural transformation
}

\author{
$\underline{\text { David G. Angeler }}^{1,2}$, Miguel Alvarez-Cobelas $^{3}$ and Salvador Sánchez-Carrillo $^{3}$
}

\begin{abstract}
Art-science approaches are mounting to increase public literacy about sustainability challenges as planet Earth swiftly moves to an uncertain future. We use data sonification, an approach that allows converting scientific data into music, to document the large-scale transformation of the agricultural sector in central Spain during the 1970s. We converted 71-year time series of inundation area and rainfall data from the freshwater marsh Las Tablas de Daimiel into a soprano and bass voice, respectively. We composed "The Lament of Las Tablas de Daimiel," which sings the biophysical disruption of the wetland due to the agricultural transformation. More generally, the song testifies to the demise of the natural aquatic environment due to unsustainable use of limited water resources in dryland countries and elsewhere. Making the mute voices of ecosystem heard may have potential to increase awareness about the unsustainable use of short water supplies and other social-ecological challenges. In the age of big data in science, data sonification may be a useful tool to represent and communicate such challenges.
\end{abstract}

Key Words: agriculture; climate; composition; data sonification; ecology; music; social-ecological change; time series; transformation; wetland

\section{INTRODUCTION}

Fast-changing social-ecological baselines pose significant challenges to humanity as planet Earth swiftly moves toward a highly uncertain future. Current social and ecological transformations not only motivate scientific research to envision and understand such challenges, they also require that the sciencebased information is transferred to sectors in society outside academia (Smith et al. 2013). Recognizing the potential to implement imaginative and practical approaches for increasing public awareness and engagement (Castree et al. 2014), collaborative art-science approaches are emerging as useful tools for representing and communicating social-ecological challenges to the public (Lesen et al. 2016).

Art-science approaches for increasing public literacy about sustainability challenges are recognized for their potential to encourage intuitive, creative thinking and engagement (Scheffer et al. 2013). This potential stems from two interacting psychological domains that influence the learning process: the affective (emotion, feeling) and the cognitive domain (thinking), which are related to the arts and the sciences, respectively (Lesen et al. 2016). Recent work suggests that stimulating both learning domains, for instance through active engagement of communities in the creative process, can be more effective than expert-based communications of knowledge to a public without training in the sciences (Evans 2014).

It remains unclear whether arts-based science communication is uniquely effective in eliciting awareness of environmental change and shaping policy and governance (Lesen et al. 2016). A limited effectiveness may stem partly from the widely recognized challenge of subjectivity inherent in many artistic representations of sustainability problems. In the worst case, subjectivity can lead to a decontextualization and a false understanding of patterns of order in nature. In turn, people may perceive sustainability problems as distant and unlinked to personal experience and exposure (Moser 2010). This highlights the need for portraying environmental problems comprehensibly for the general public to trigger changes in community behavior, increase involvement, and expedite action (Evans 2014).

Most art-science-based approaches are based on the fine arts and dance (Galafassi et al. 2018). Music may comprise an alternative way to represent the temporally dynamic structure of ecosystems and other complex systems, allowing for promising creative connections between music and sustainability problems (Angeler 2016a, Kagan and Kirchberg 2016). Traditionally, nature has inspired many composers, including Debussy, Messiaen, Saariho, and Takemitsu among many others, and patterns of nature are artistically reflected in their compositions. Other ways of acoustic representation of nature is through the exploration of its soundscape (Schafer 1976). Exploring sounds is leading to an emerging research area, which strives to make all forms of sounds and noises in the environment-i.e., nature's music - directly accessible to human auditory perception and emotion (Pijanowska et al. 2011). However, social and ecological systems are complex, and many of their component structures and processes are not accessible to the human senses (e.g., seasonal variation of planktonic algae or plate tectonics). Approaches that can make mute voices heard may contribute to an alternative representation and understanding of nature and have potential for environmental communication.

Data sonification is an emergent field that builds on the production of sound signals by using scientific data (Hermann 2008, Worrall 2009). Last and Usyskin (2015) suggested that time series data are particularly well suited for sonification because there are natural parallels with musical sounds. Both music and time series data are sequential, have duration, and evolve over time. Data sonification has been used in a climatic change context to represent acoustically increasing planetary temperatures (Crawford 2013), rapidly decreasing sea-ice volume in the Arctic (the Arctic death spiral [Robinson 2013]), or temperature fluctuations in a lake (Lake Annie song [Gaiser 2016]). We aim

${ }^{1}$ Swedish University of Agricultural Sciences, Department of Aquatic Sciences and Assessment, Uppsala, Sweden, ${ }^{2}$ University of Nebraska Lincoln, School of Natural Resources, Lincoln, NE, USA, ${ }^{3}$ National Museum of Natural Sciences, MNCN-CSIC, Department of Biogeochemistry and Microbial Ecology, Madrid, Spain 
Fig. 1. Map of Las Tablas de Daimiel in Central Spain. Shown are the contours of the national park and the water flow paths of rivers that contribute to wetland flooding.

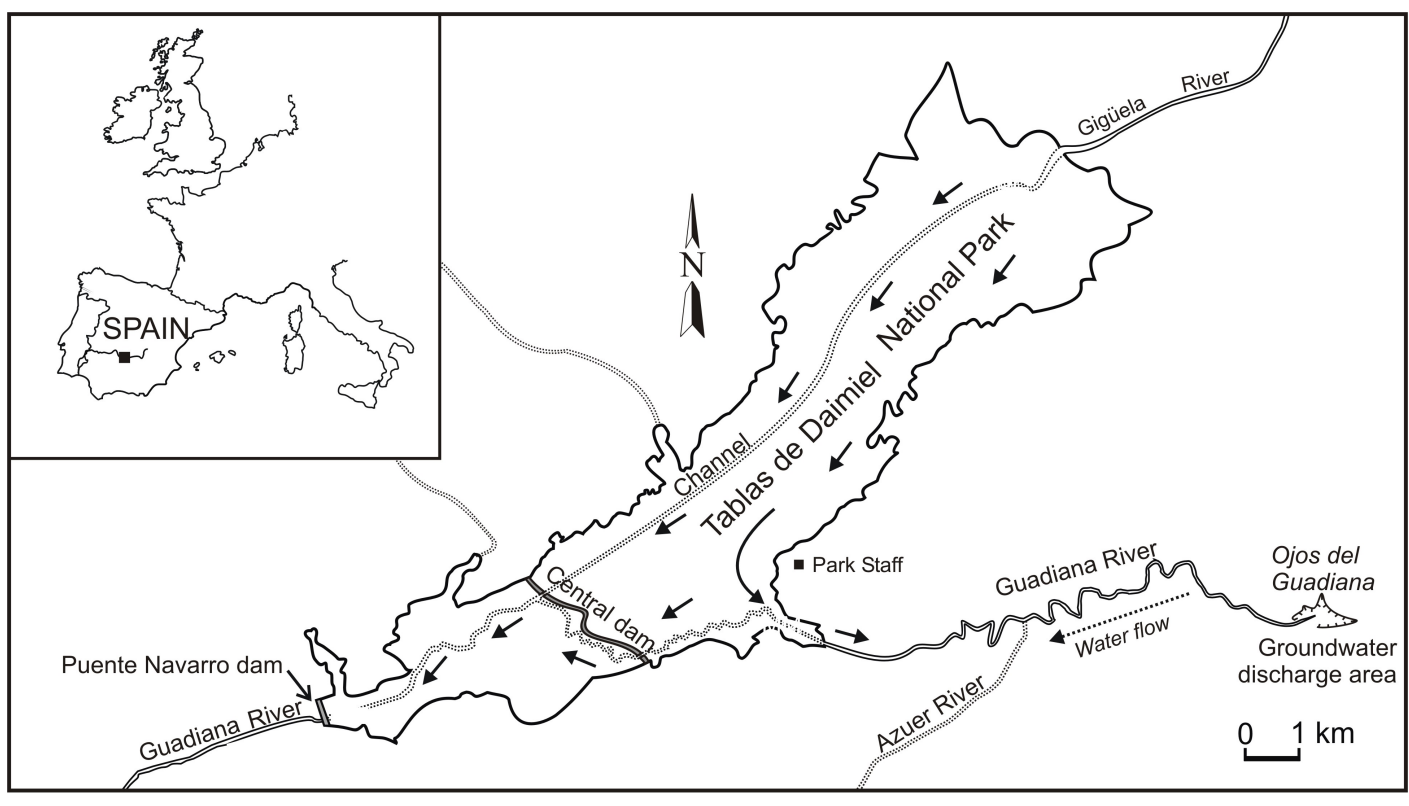

to represent musically the profound transformation of the agricultural sector in central Spain in the 1970s. We translate 71y time series (1945-2016) of inundation area and rainfall data into a lament, which documents the irreversible degradation of the wetland as a result of this profound social-ecological transformation. The song is representative of the general decline of the natural aquatic environment due to unsustainable use of limited water resources in dryland countries (Alvarez-Cobelas et al. 2005). It may serve as a vehicle to increase awareness about the potential future consequences of continued unsustainable use of short water supplies for human health, equality, and conflicts (Horner-Dixon 1991, McMichael et al. 2008).

In the next sections, we first provide an overview of the wetland, Las Tablas de Daimiel. We describe how its historical hydrological functioning became disrupted as a result of the social-ecological transformation. We focus on hydrology because it essentially steers all patterns and processes in wetland ecology (Mitsch and Gosselink 2000). After this contextualization, we use inundation area and rainfall data and describe our approach for composing "The Lament of Las Tablas de Daimiel." Finally, we discuss this lament within the context of environmental communication and sustainability.

\section{THE WETLAND}

Las Tablas de Daimiel (TDNP) is a remnant marshland of a once extended floodplain area $\left(150-250 \mathrm{~km}^{2}\right)$ in Central Spain $\left(39^{\circ}\right.$ $08^{\prime} \mathrm{N}, 3^{\circ} 43^{\prime} \mathrm{W}$ ) (Fig. 1). The wetland provides testimony to largescale agricultural transformation during the second half of the 20 th century in an area where the climate is dry and water is scarce. This social-ecological transformation has been described in depth by Sánchez-Carrillo and Angeler (2010), and can be briefly summarized as follows.
Until the 1970s, the wetland's hydrological and ecological functioning was maintained by the flooding of two rivers in the extended alluvial plain (Gigüela and Guadiana) (SánchezCarrillo and Alvarez-Cobelas 2010). The floodplain was also the natural groundwater discharge zone of the Llanura Manchega Occidental aquifer due to the closeness of the groundwater table to the surface (Sánchez-Carrillo and Alvarez-Cobelas 2010). Until the 1950s, small water-mill dams helped retain water in TDNP. Nowadays, none of them are functional but they remain as cultural heritage in the wetland. As a result of the complex interaction between surface flooding, groundwater discharge, and damming, TDNP's inundation area followed regular cycles of expansions with rainfalls in autumn and winter, and contractions as a result of summer droughts associated with the semiarid, Mediterranean climate (Fig. 2) (Sánchez-Carrillo and AlvarezCobelas 2010). These clearly historically defined hydrological patterns led to a unique, partly endemic fauna and flora, which in turn provided ecosystem services in the form of fishing, cattle breeding, and bird hunting, and not least, a source of inspiration for art (Alvarez-Cobelas et al. 2010, Sánchez-Carrillo et al. 2010).

From 1974, this region experienced a significant agrarian transformation, when traditional agriculture comprised of cultivating rain-fed lands (wheat, vineyard, and olive) was replaced by sustained groundwater irrigation agriculture of herbaceous crops (e.g., maize, alfalfa, beet, melon), which have high water requirements. During the period between 1974 and 1989, the area of irrigated land increased by $324 \%$ and groundwater extractions rose from 152 to $568 \mathrm{Mm}^{3} \mathrm{yr}^{-1}$ (SánchezCarrillo et al. 2010). These rates exceeded groundwater recharge and caused a disconnect between the wetland and the aquifer due to dropping water levels. Consequently, the entire hydrological regime in the wetland changed and became dependent entirely on 
erratic riverine inputs and occasional interbasin water transfers from the Tajo-Segura catchment (Sánchez-Carrillo and AlvarezCobelas 2010). Hydrological changes were further exacerbated when several drought periods caused the wetland to almost entirely dry up during several years (e.g., 1991-1995, 2005-2009). The disruption of the hydrological regime of TDNP, which was due to the loss of buffering surface water loss by groundwater discharge, is manifested in the highly irregular inundation area patterns after 1974 (Fig. 3). Contrary to the inundation area, rainfall varied strongly intra- and interannually and showed less distinctive patterns before and after the transformation in terms of mean ( $37 \mathrm{~mm} \mathrm{month}^{-1}$ before, $32 \mathrm{~mm} \mathrm{month}^{-1}$ after), maximal (163 mm month ${ }^{-1}$ before, $179 \mathrm{~mm} \mathrm{month}^{-1}$ after), and minimum $\left(0 \mathrm{~mm} \mathrm{month}{ }^{-1}\right.$ before and after) precipitation (Fig. 3). Thus, characterizing TDNP's complex hydrological functioning using inundation area and rainfall variables shows that its hydrological balance depends more on the consequences of human action than on meteorological factors (Sánchez-Carrillo and AlvarezCobelas 2010).

Fig. 2. Aerial photographs of Las Tablas de Daimiel during a wet (upper panel) and a dry (lower panel) period. Courtesy of Santos Cirujano.

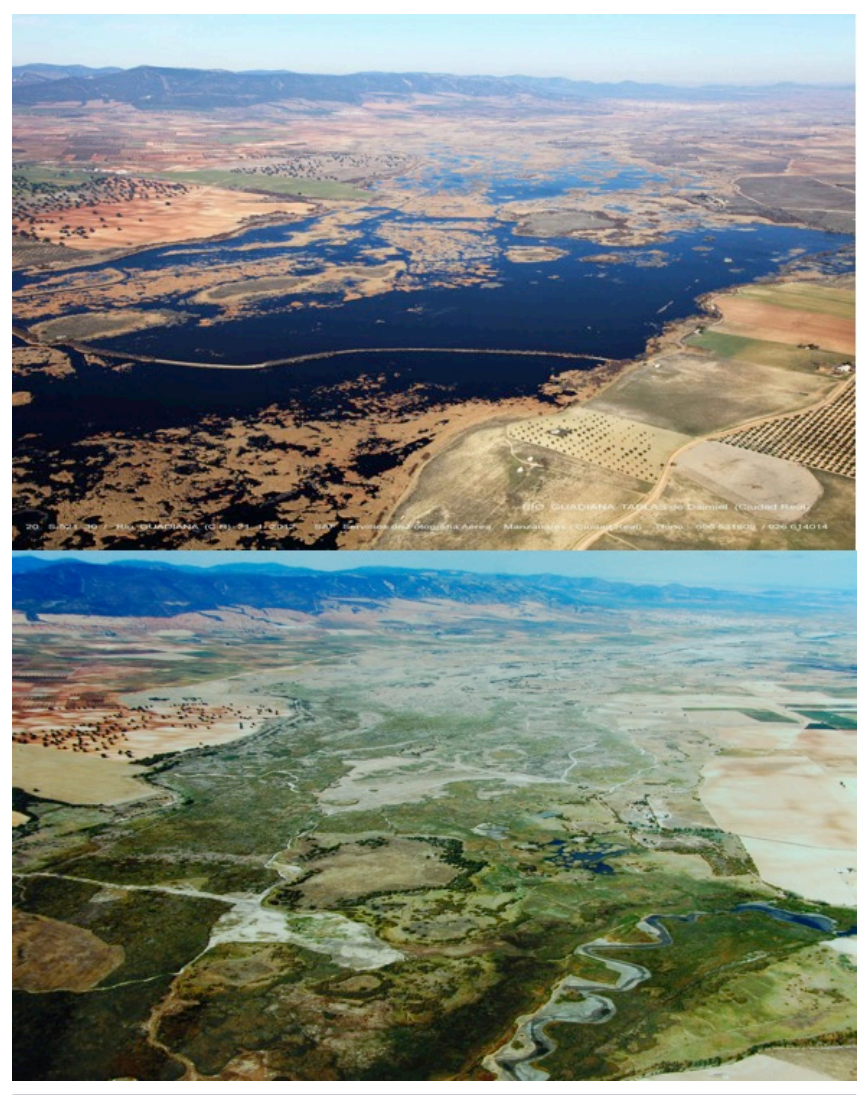

Enacting the European Agro-Environmental Program on water demands for irrigation resulted in pumping restrictions that reduced irrigation area. However, these measures were not sufficient for restoring the groundwater table to the levels prior to 1970 , and the aquifer was declared definitely overexploited in 1994 (Cirujano et al. 2010). Uncommonly humid periods registered in 1997-1998 and 2004-2005 and more recently 20102014 resulted in a temporary recovery of the aquifer (Castaño et al. 2013). However, this triggered increased farmers' pressure on policy to increase groundwater extraction for agricultural irrigation. Consequently, this resulted in a minimal recovery of the wetland inundation area.

Since the 1950s, the extent of the wetland has been reduced and its ecological integrity has been strongly impacted (SánchezAndrés et al. 2010). Degradation was due to many sources of anthropogenic activities, including a controversial history of desiccation in order to eradicate malaria and increase farming lands. Later, water quality deterioration by riverine wastewater discharges and agriculture runoff pollution aggravated the problem. Despite the implementation of hydrological remediation plans since the mid-1970s and legal protection and conservation (RAMSAR convention, European Habitat Directive (97/62/EC), UNESCO, Biosphere Reserve (Man and the Biosphere Programme, the La Mancha Húmeda region), wetland degradation has never improved. Remaining native species of conservation interest (e.g., sawgrass [Cladium mariscus]) are at risk of extinction, and the once diverse fish fauna has been replaced by a few dominant invasive species (common carp [Cyprinus carpio], pumpkinseed sunfish [Lepomis gibbosus], mosquito fish [Gambusia holbrooki]).

The wetland can be considered to operate in a degraded alternative regime from which the return to its predisturbance regime is highly unlikely. The transformation of TDNP comprises a loss of social-ecological heritage, value, and potential. This loss has inspired the name of our composition: The Lament of Las Tablas de Daimiel.

\section{APPROACH}

We used data sonification for auditory documentation of TDNP's transformation that resulted from the lasting changes of the agricultural sector in Central Spain in the second half of the last century. A broad spectrum of approaches can potentially be applied in terms of translating biophysical variables into music scores and to attempt different levels of complexity of the music. We created a simple song structure, using two variables as the voices of TDNP to document its transformation.

We obtained inundation area (ha) data from the records of the Long Term Ecological Research (LTER) site Las Tablas de Daimiel (LTER-Spain; LTER_EU_ES_026), and rainfall (mm month $^{-1}$ ) data from meteorological stations located at the western shore of the wetland (1961-2016) and the nearby city of Daimiel (1945-1960). Inundation area or flooded area (ha) was translated into the first voice in the music score. We chose inundation area because it is a surrogate that integrates the complex hydrological functioning of the wetland, which, in turn, influences all biophysical processes, including ecosystem service provisioning and resilience (Angeler et al. 2013). The second variable (voice) was comprised of rainfall patterns. Including precipitation in the scores covers regional meteorological aspects. Despite contributing to the regulation of TDNP's hydrological balance, precipitation is largely independent from inundation area (Sánchez-Carrillo and Alvarez-Cobelas 2010).

Both variables were measured continuously in monthly intervals since 1945, which provided a fine temporal resolution for 
Fig. 3. Time series of monthly values of inundation area (ha) of Las Tablas de Daimiel and amounts of seasonal rainfall (mm month-1) from 1946 to 2016.
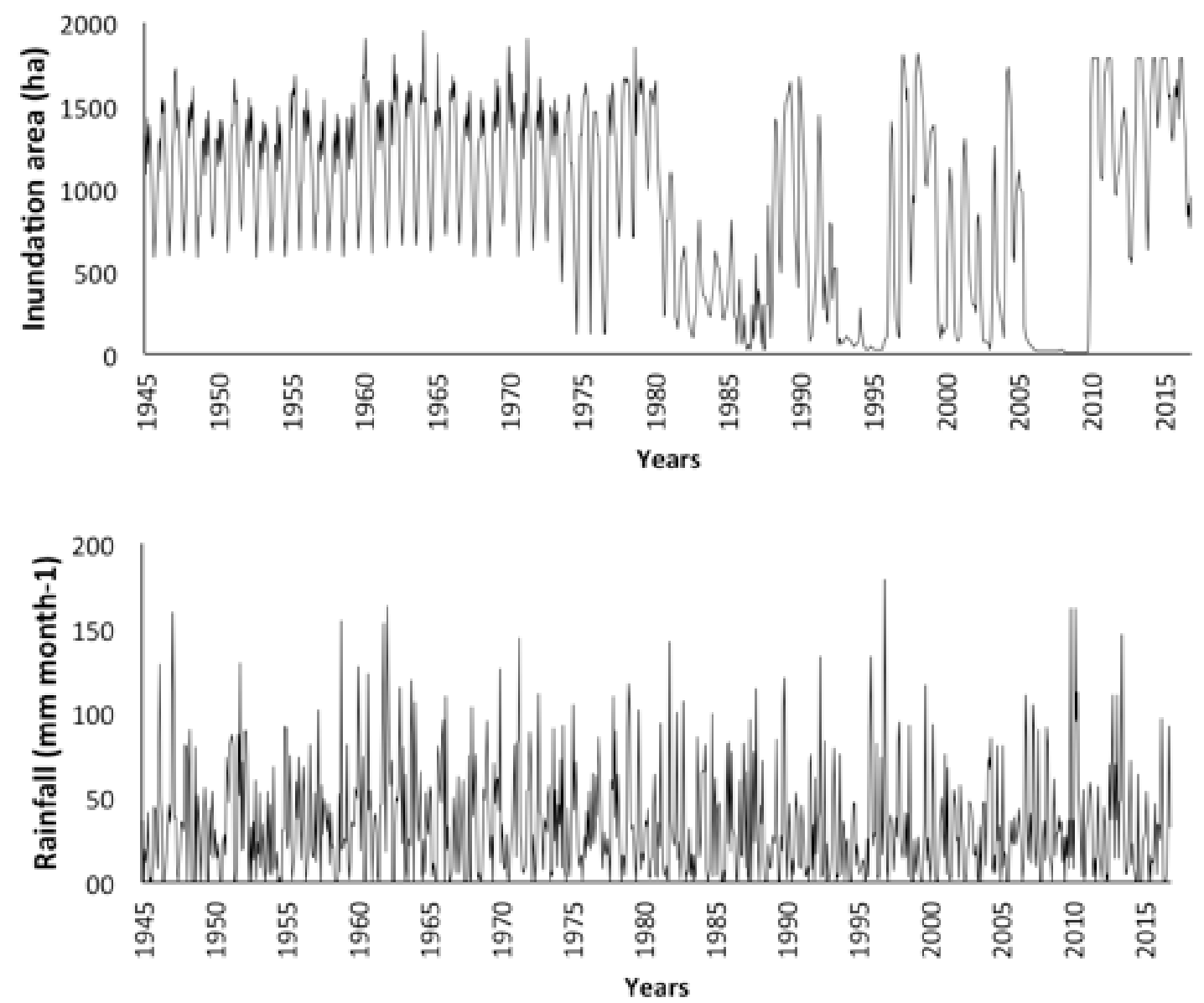

documenting the transformation. To prepare the first voice (inundation area), the data, which ranged between 10 and 1900 ha, were rank-ordered in 100-ha intervals, which resulted in 21 intervals. To emphasize the melancholic nature of a lament, we chose to compose our song in a minor rather than a major scale. We used A minor as the key signature for simplicity because it has no flat and sharp pitches (A, B, C, D, E, F, G, A). The one-line octave $\mathrm{A}$ was assigned to the average inundation area rank in the time series (900-1000 ha), and every inundation area rank interval above and below was coded with the corresponding pitch in the A minor scale. This resulted in pitches ranging from small octave F (lowest inundation area rank: 0-100 ha) to three-line octave $\mathrm{d}$ (highest inundation area rank: greater than 1900 ha).

Similar to inundation area, rainfall, which comprised the second voice in the song, was rank-ordered from lowest $(0-10 \mathrm{~mm}$ month ${ }^{-1}$ ) to highest (greater than $100 \mathrm{~mm} \mathrm{month}^{-1}$ ). Instead of using monthly data, we arbitrarily chose seasonal means by averaging three spring, summer, autumn, and winter months to differentiate the voice of rainfall from the voice of inundation area. The great octave A was assigned to the average rainfall rank in the time series $\left(30-40 \mathrm{~mm} \mathrm{month}^{-1}\right)$, and every rainfall rank interval above and below was coded similarly as the inundation area voice with the corresponding pitch in A minor. This resulted in pitches ranging from great octave $\mathrm{E}$ (lowest rainfall rank: 0-10 $\mathrm{mm} \mathrm{month}{ }^{-1}$ ) to small octave d (highest rainfall rank: greater than $\left.120 \mathrm{~mm} \mathrm{month}^{-1}\right)$.

The notes corresponding to inundation area and rainfall were then scored in the freeware Musescore 2.1.0 (https://musescore. org/). We set the time signature to $12 / 8$, which aligns well with the time series length and resolution of inundation area and rainfall. That is, with this time signature, every month (inundation area) becomes an eight note and every season (rainfall) a dotted quarter note within a measure. Each measure in the composition corresponds to one year in the time series. Given the 864 months in the entire time series, the composition consisted of 72 measures. The tempo was set to $1 / 8=180$, which compressed the 71 -year time series into a $4 \mathrm{~min}$. $52 \mathrm{sec}$. song duration. We scored inundation area in treble clef and the rainfall in bass clef, and chose the Ahh Choir option in the Musescore Mixer to express inundation area as a soprano voice and rainfall as a bass voice. We hyphenated identical notes and added a last measure (measure 73) to round up the song rather than letting it finish abruptly with 
the last note of the time series. We also emphasized the drought effects with dynamics increasing from mezzo forte $(m f)$ to fortissimo $(f f)$. Besides these edits, no modifications in the scoring were carried out in order to maintain the musical expressions of the original inundation area and rainfall data as much as possible. The sheet of the Lament of Las Tablas de Daimiel is provided in Appendix 1.

\section{HEARING THE LAMENT OF LAS TABLAS DE DAIMIEL}

The Lament of Las Tablas de Daimiel can be listened to in the audio file in Appendix 2. The soprano voice reflects the cyclicity of inundation area, with higher pitches reflecting periods of higher inundation during winter and spring, and lower pitches reflecting periods of lower inundation during drier summer and fall months. These seasonal patters showed some variability among years - i.e., among measures in the composition-and were recurrent until the hydrological disruption became evident as a result of the agricultural transformation in 1974. This disruption manifests in the Lament of Las Tablas de Daimiel by lower pitches and more chaotic seasonal patterns starting at measure 38, and the sustained low pitches during several measures (from 48 to 51 and 61 to 65 ), which reflect the supraseasonal droughts.

Similar to the soprano voice, the bass voice captures seasonality in rainfall, with lower amounts of precipitation manifesting in lower pitches in summer. Despite interannual variability in rainfall, the range of pitches across seasons remained relatively constant in the song, both before and after the agricultural transformation (Appendix 1 and 2).

\section{DISCUSSION}

In the age of big data in science, data sonification has increasing potential to unveil social-ecological system changes that are hidden to human perception. We applied this approach to document the social-ecological transformation in the agricultural sector of Central Spain and how this change disrupted the hydrological functioning of a marshland.

Data can be expressed through music in different ways (Robinson 2013), and our representation of the agricultural transformation through a soprano and bass voice in the Lament of Las Tablas de Daimiel is therefore subjective. Despite this, there is evidence from experimental research that listeners without formal training in music can make useful distinctions in the data (Last and Usyskin 2015), which highlights the usefulness of data sonification for sustainability communication. This links to an exhaustive body of research in musicology and psychology about the ability of music to elicit human tensions; e.g., music creating synaesthetic experiences (Kagan and Kirchberg 2016), developing reflection (Merleau-Ponty 1969, De Certeau 1984), training critical systems thinking (Bausch 2012), and linking imagination and the complex aesthetic creativity in the listener (Hargreaves et al. 2012). Further research at the intersection between music and psychology could assess how data sonification, specifically the choice of representation methods (e.g., musical genres, instruments), might influence the application of the approach to the communication of sustainability challenges.

While the representation potential of sustainability challenges through sonification is high, it remains unclear whether artsbased science communication in general is uniquely effective in eliciting awareness of environmental change and shaping policy and governance (Lesen et al. 2016). It is likely that the provision of context of specific sustainability challenges before listening to the songs may help the learning process. Also, several complementary representations based on historical and cultural aspects of the same problem may foster learning. The visual arts that cover different time periods may provide such additional learning support (Thomsen 2015, Brinley Buckley et al. 2017). Specifically, in the case of Las Tablas de Daimiel, fine art by Juan D'Opazo and Ignacio Meco, together with historical photographs available in private and public collections (the image collection of the Water and Wetland Center of La Mancha), could complement our lament; so may the aerial images that capture snapshots of dry and wet conditions in the wetland (Fig. 2). Also, regular painting and photography workshops about Las Tablas de Daimiel create art that can catalyze people's connection with the wetland.

More generally, approaches from other disciplines can additionally support data sonification for learning about sustainability challenges. Ecocriticism studies text, film, advertising, and other media to portray human-nature relationships variously from scholarly, political, and/or activist viewpoints (Gladwin 2017). Sound ecology studies the acoustic effects generated by organisms, non-biological sources, and humans on organisms in the environment (Schafer 1976, Pijanowska et al. 2011). Sound ecology and data sonification may not be mutually exclusive for acoustically communicating sustainability problems. Sound ecology represents the sounds in the environment that can be heard, while data sonification extracts sounds that are hidden in scientific data and which often capture patterns and processes in nature that are intangible to humans. These approaches combined provide a broader spectrum of sounds inherent in ecosystems, which may spur thinking and elicit awareness in the context of sustainability literacy.

In summary, transdisciplinary approaches are needed to integrate different knowledge domains (Muhar et al. 2013), and provide opportunities to link the generation of knowledge with transforming societies (Vilsmaier and Lang 2015). The Lament of Las Tablas de Daimiel demonstrates the application of data sonification as a tool to represent and potentially communicate sustainability challenges through music. The song not only testifies to the agricultural transformation in Central Spain in the 1970s; it represents the fate of wetlands around the globe that face substantial threats from human activity (Junk et al. 2013). Wetlands are biodiversity hotspots, comprise habitat for emblematic wildlife, and provide a host of ecosystem services to humans (Mitsch and Gosselink 2000). It is therefore necessary to maximize conservation efforts to guarantee the benefits wetlands provide to people. Public awareness and engagement are needed to trigger shifts in policy, and to move away from practices that may compromise human health, equality, and conflicts when climate change potentially exacerbates the continued unsustainable use of short water supplies (Angeler 2016b). This paper and other work (Crawford 2013, Robinson 2013, Gaiser 2016) highlight the potential of data sonification to represent such challenges. Implementing this approach for communicating sustainability can be highly valuable as fast social-ecological change in the Anthropocene shifts systems of people and nature to an uncertain future. 
Responses to this article can be read online at:

http://www.ecologyandsociety.org/issues/responses. $\mathrm{php/10055}$

\section{Acknowledgments:}

This research was funded by the Swedish Research Councils Formas (2014-1193) and VR (2014-5828).

\section{LITERATURE CITED}

Alvarez-Cobelas, M., S. Cirujano, and A. Meco. 2010. The man and Las Tablas de Daimiel. Pages 241-254 in S. Sánchez-Carrillo and D. G. Angeler, editors. Ecology of threatened semi-arid wetlands. Springer, London, UK. http://dx.doi.org/10.1007/978-90-481-9181-9 11

Alvarez-Cobelas, M., C. Rojo, and D. G. Angeler. 2005. Mediterranean limnology: current status, gaps and the future. Journal of Limnology 64:13-29. http://dx.doi.org/10.4081/ jlimnol.2005.13

Angeler, D. G. 2016a. Heavy metal music meets complexity and sustainability science. SpringerPlus 5:1637. http://dx.doi. org/10.1186/s40064-016-3288-9

Angeler, D. G. 2016b. Viewing biodiversity through the lens of science... and art! SpringerPlus 5:1174. http://dx.doi.org/10.1186/ $\underline{\text { 440064-016-2831-Z }}$

Angeler D. G., C. R. Allen, C. Rojo, M. Alvarez-Cobelas, M. A. Rodrigo, and S. Sánchez-Carrillo. 2013. Inferring the relative resilience of alternative states. PLoS ONE 8(10):e77338. http:// dx.doi.org/10.1371/journal.pone.0077338

Bausch, C. 2012. Sonatas for sustainability: How musical training imparts important qualities and skills for sustainability. Sustainability Reviews 3(3). [online] URL: http://www. thesustainabilityreview.org/articles/sonatas-for-sustainability-howmusical-training-imparts-important-qualities-and-skills-for-sustainability

Brinley Buckley, E. M., C. R. Allen, M. Forsberg, M. Farrell, and A. J. Caven. 2017. Capturing change: the duality of time-lapse imagery to acquire data and depict ecological dynamics. Ecology and Society 22(3):30. http://dx.doi.org/10.5751/ES-09268-220330

Castaño, S., R. Mediavilla, J. I. Santisteban, A. de la Losa, and P. Martínez-Santos. 2013. Contribution to the knowledge of the hydrogeological behavior of Tertiary-Quaternary boundary in the vicinity of Las Tablas de Daimiel National Park. Geogaceta 54:111-114.

Castree, N., W. M. Adams, J. Barry, D. Brockington, B. Büscher, E. Corbera, D. Demeritt, R. Duffy, U. Feit, K. Neves, et al. 2014. Changing the intellectual climate. Nature Climate Change 4:763-768. http://dx.doi.org/10.1038/nclimate2339

Cirujano, S., M. Álvarez-Cobelas, and C. Ruíz de la Hermosa. 2010. Analysis of applied environmental management strategies for wetland conservation during the last 30 years: a local history. Pages 229-237 in S. Sánchez-Carrillo and D.G. Angeler, editors. Ecology of threatened semi-arid wetlands. Springer, London, UK. http://dx.doi.org/10.1007/978-90-481-9181-9_10
Crawford, D. 2013. The song of our warming planet. [online] URL: https://ensia.com/videos/a-song-of-our-warming-planet/

De Certeau, M. 1984. The practice of everyday life. University of California Press, Berkeley, California, USA.

Evans, E. 2014. How green is my valley? The art of getting people in Wales to care about climate change. Journal of Critical Realism 13:304-325. http://dx.doi.org/10.1179/1476743014Z.00000000032

Gaiser, E. 2016. Lake Annie song. TEDx Talks. [online] URL: https://www.youtube.com/watch?v $=\mathrm{m} 7 \mathrm{fCmHG} 3 \mathrm{~h} 7 \mathrm{k}$

Galafassi, D., S. Kagan, M. Milkoreit, M. Heras, C. Bilodeau, S. J. Bourke, A. Merrie, L. Guerrero, G. Pétursdóttir, and J. D. Tàbara. 2018. 'Raising the temperature': the arts in a warming planet. Current Opinion in Environmental Sustainability 31:71-79. http://dx.doi.org/10.1016/j.cosust.2017.12.010

Gladwin, D. 2017. Ecocriticism. Oxford bibliographies. [online] URL: http://www.oxfordbibliographies.com/view/document/ obo-9780190221911/obo-9780190221911-0014.xml http://dx.doi. org/10.1093/obo/9780190221911-0014

Hargreaves, D., D. Miell, and R. MacDonald. 2012. Musical imaginations. Multidisciplinary perspectives on creativity, performance and perception. Ashgate, Farnham, UK.

Hermann, T. 2008. Taxonomy and definitions for sonification and auditory display. Proceedings of the 14th International Conference on Auditory Display. IRCAM, Paris, France.

Horner-Dixon, T. F. 1991. On the threshold: environmental changes as causes of acute conflict. International Security 16:76-116. http://dx.doi.org/10.2307/2539061

Junk, W. J., S. An, C. M. Finlayson, B. Gopal, J. Květ, S. A. Mitchell, W. J. Mitsch, and R. D. Robarts. 2013. Current state of knowledge regarding the world's wetlands and their future under global climate change: a synthesis. Aquatic Sciences 75:151-167. http://dx.doi.org/10.1007/s00027-012-0278-z

Kagan, S., and V. Kirchberg. 2016. Music and sustainability: organizational cultures towards creative resilience - a review. Journal of Cleaner Production 135:1487-1502. http://dx.doi. org/10.1016/j.jclepro.2016.05.044

Last, M., and A. Usyskin. 2015. Listen to the sound of data. Pages 419-446 in A. K. Baughman, J. Gao, J,-Y. Pan, and V. A. Petrushin, editors. Multimedia data mining and analytics. Springer, Heidelberg, Germany. http://dx.doi.org/10.1007/978-3-319-14998-1_19

Lesen, A. E., A. Rogan, and M. J. Blum. 2016. Science communication through art: objectives, challenges, and outcomes. Trends in Ecology \& Evolution 31:657-660. http://dx. doi.org/10.1016/j.tree.2016.06.004

McMichael, A. J., S. Friel, A. Nyong, and C. Corvalan. 2008. Global environmental change and health: impacts, inequalities, and the health sector. British Medical Journal 336:191-194. http:// dx.doi.org/10.1136/bmj.39392.473727.AD

Merleau-Ponty, M. 1969. The prose of the world (La prose du monde). Editions Gallimard, Paris, France.

Mitsch, W. J., and J. G. Gosselink. 2000. Wetlands. Third edition. Wiley, New York, USA. 
Moser, S. C. 2010. Communicating climate change: history, challenges, process and future directions. WIRE's Climate Change 1:31-53. http://dx.doi.org/10.1002/wcc.11

Muhar, A., J. Visser, and J. van Breda. 2013. Experiences from establishing structured inter- and transdisciplinary doctoral programs in sustainability: a comparison of two cases in South Africa and Austria. Journal of Cleaner Production 61:122-129. http://dx.doi.org/10.1016/j.jclepro.2013.07.031

Pijanowski, B. C., L. J. Villanueva-Rivera, S. L. Dumyahn, A. Farina, B. L. Krause, B. M. Napoletano, S. H. Gage, and N. Pieretti. 2011. Soundscape ecology: the science of sound in the landscape. BioScience 61:203-216. http://dx.doi.org/10.1525/ bio.2011.61.3.6

Robinson, A. L. 2013. Arctic death spiral. Piano version: http:// youtu.be/bL7D5eR1Dxk; spectrally modified version with comb filters: http://youtu.be/KfJHmyK YpeE; Arctic Sea Ice Minimum Volumes 1979-2012: http://youtu.be/YgiMBxaL19M

Sánchez-Andrés, R., M. O. Viedma, and S. Sánchez-Carrillo. 2010. The effects of anthropogenic stressors on wetlands loss and habitat quality deterioration in the upper Guadiana river basin: a long-term assessment (1970-2000). Pages 85-107 in S. SánchezCarrillo and D. G. Angeler, editors. Ecology of threatened semiarid wetlands. Springer, London, UK.

Sánchez-Carrillo, S., and M. Álvarez-Cobelas. 2010. Climate and hydrologic trends: climate change versus hydrologic overexploitation as determinants of the fluctuating wetland hydrology. Pages 45-83 in S. Sánchez-Carrillo and D. G. Angeler, editors. Ecology of threatened semi-arid wetlands. Springer, London, UK. http://dx. doi.org/10.1007/978-90-481-9181-9 3

Sánchez-Carrillo, S., and D. G. Angeler. 2010. Ecology of threatened semi-arid wetlands. Springer, London, UK. http://dx. doi.org/10.1007/978-90-481-9181-9

Sánchez-Carrillo, S., D. G. Angeler, S. Cirujano, and M. AlvarezCobelas. 2010. The wetland, its catchment settings and socioeconomic relevance. Pages 3-20 in S. Sánchez-Carrillo and D. G. Angeler, editors. Ecology of threatened semi-arid wetlands. Springer, London, UK. http://dx.doi.org/10.1007/978-90-481-9181-9 1

Schafer, R. M. 1976. The soundscape. Our sonic environment and the tuning of the world. Destiny Books, Rochester, Vermont, USA.

Scheffer, M., J. Bascompte, T. K. Bjordam, S. R. Carpenter, L. B. Clarke, C. Folke, P. Marquet, N. Mazzeo, M. Meerhoff, O. Sala, and F. R. Westley. 2015. Dual thinking for scientists. Ecology and Society 20(2):3. http://dx.doi.org/10.5751/ES-07434-200203

Smith, B., N. Baron, C. English, H. Galindo, E. Goldman, K. McLeod, M. Miner, and E. Neeley. 2013. COMPASS: navigating the rules of scientific engagement. PLoS Biol 11(4):e1001552. http://dx.doi.org/10.1371/journal.pbio.1001552

Thomsen, D. C. 2015. Seeing is questioning: prompting sustainability discourses through an evocative visual agenda. Ecology and Society 20(4):9. http://dx.doi.org/10.5751/ES-07925-200409

Vilsmaier, U., and D. J. Lang. 2015. Making a difference by marking the difference: constituting in-between spaces for sustainability learning. Current Opinion in Environmental Sustainability 16:51-55. http://dx.doi.org/10.1016/j.cosust.2015.07.019
Worrall, D. 2009. An introduction to data sonification. Pages 312-333 in R. T. Dean, editor. The Oxford handbook of computer music. Oxford University Press. http://dx.doi.org/10.1093/ oxfordhb/9780199792030.013.0016 


\section{The Lament of Las Tablas de Daimiel}

David G. Angeler

$d=180$

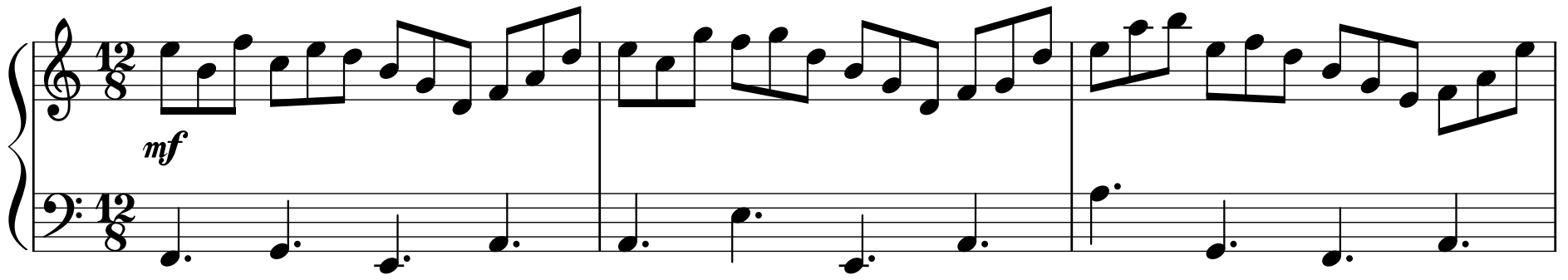

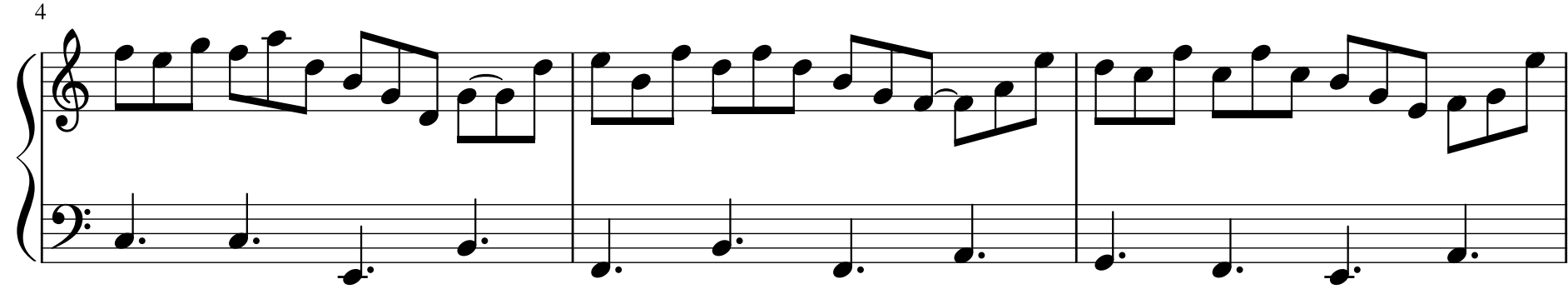

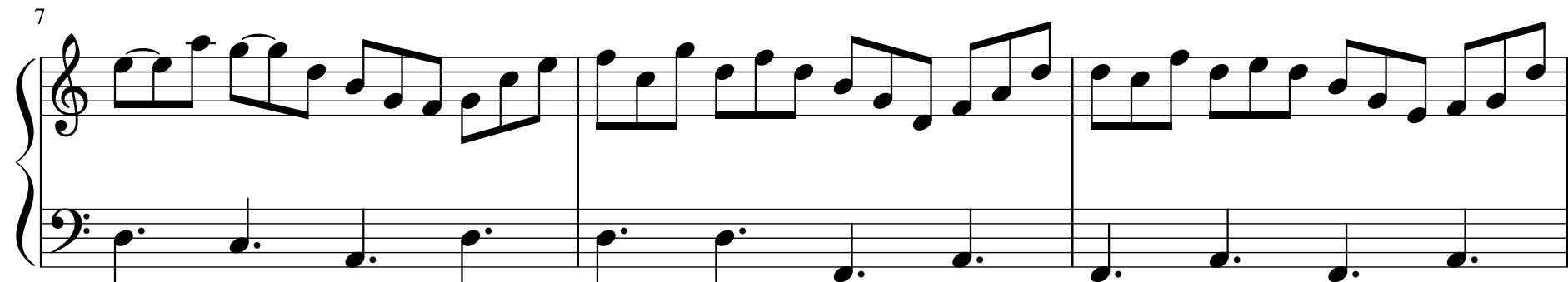

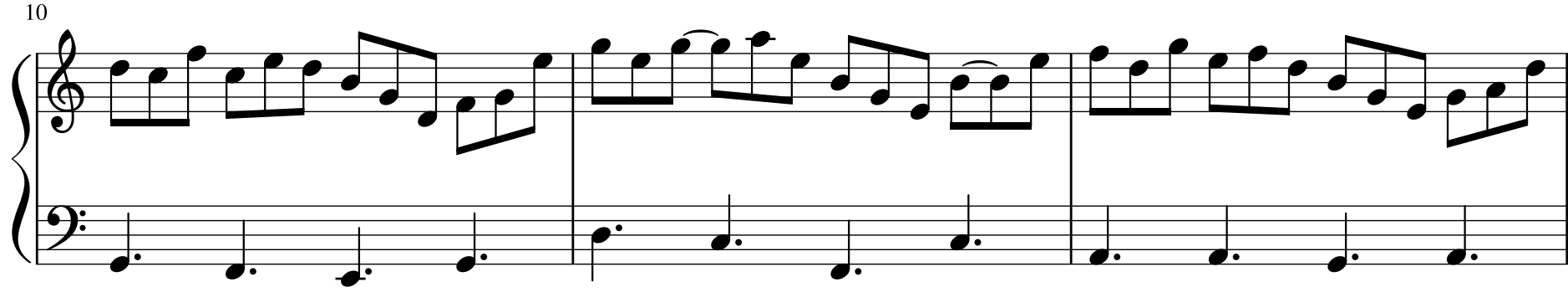

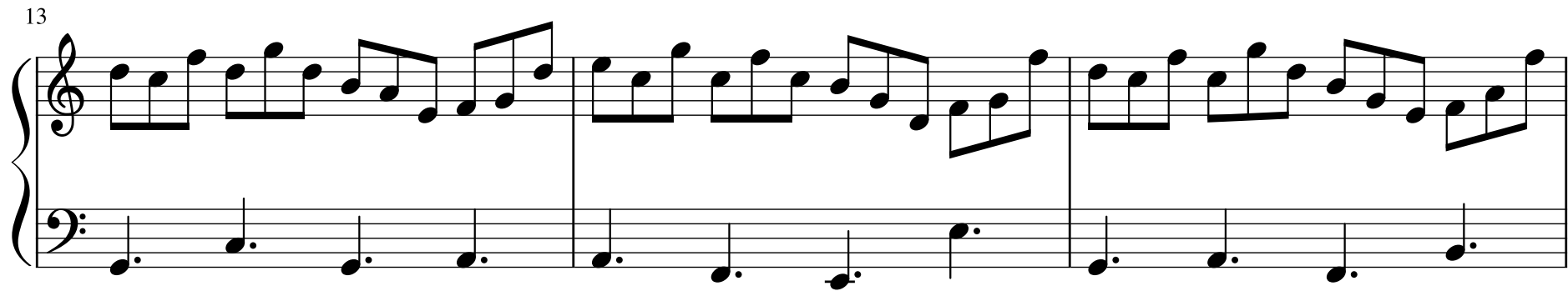




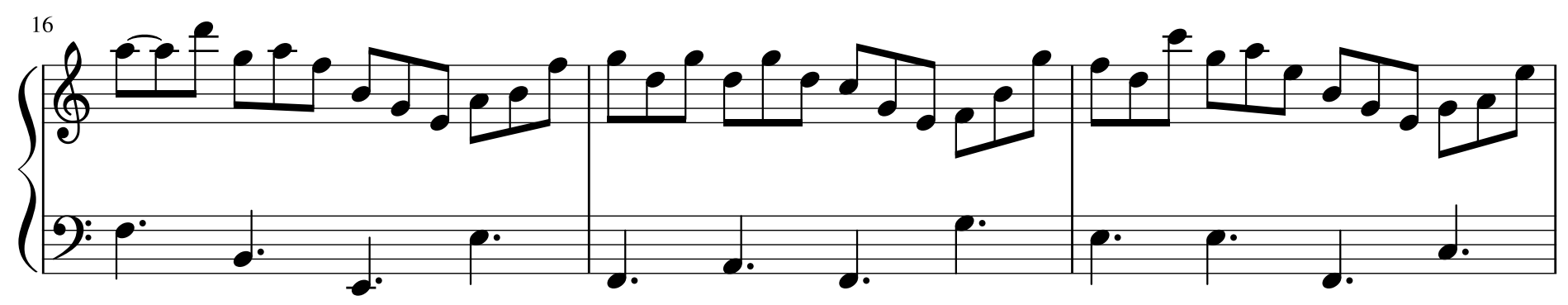

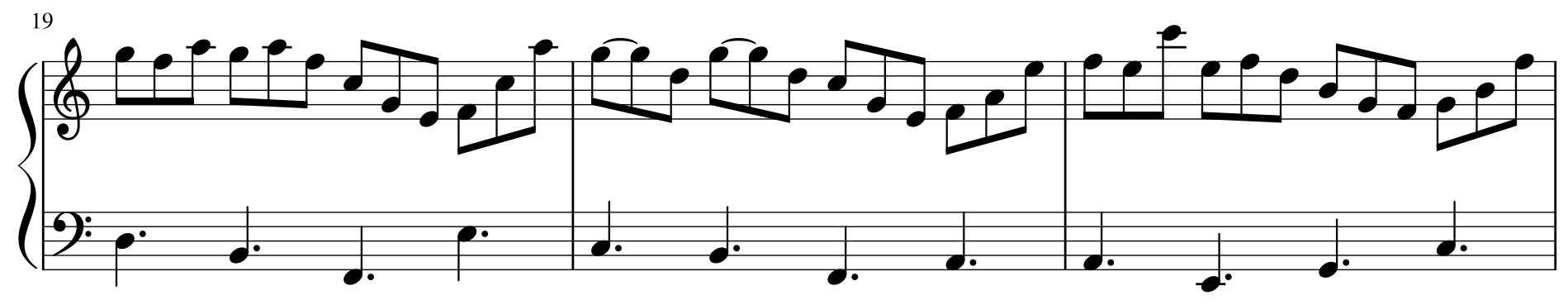

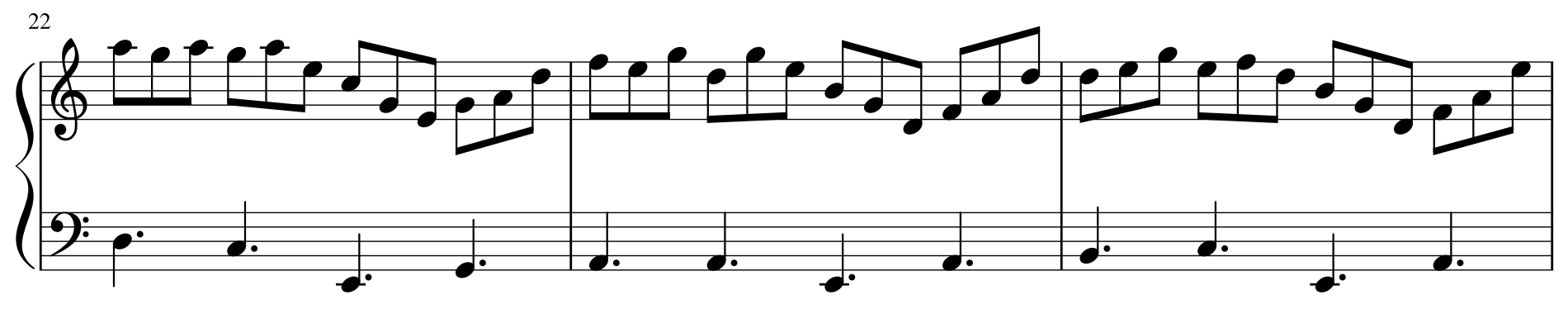

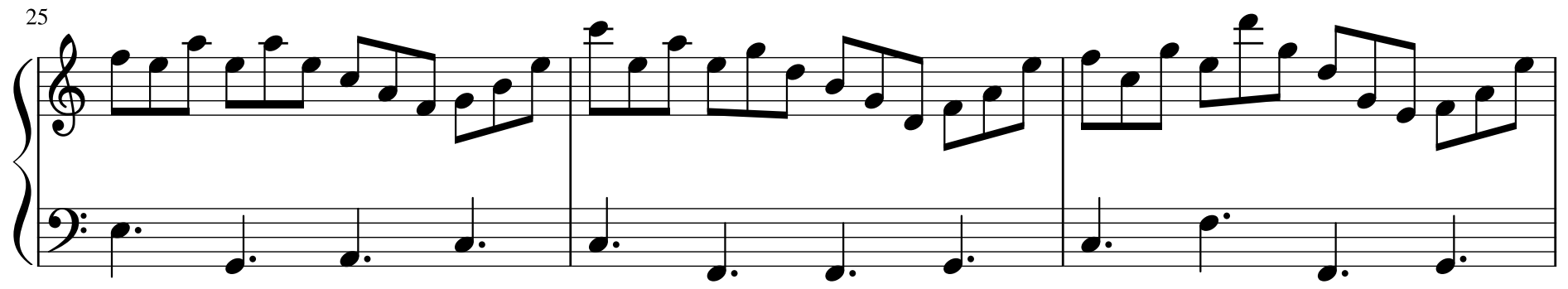

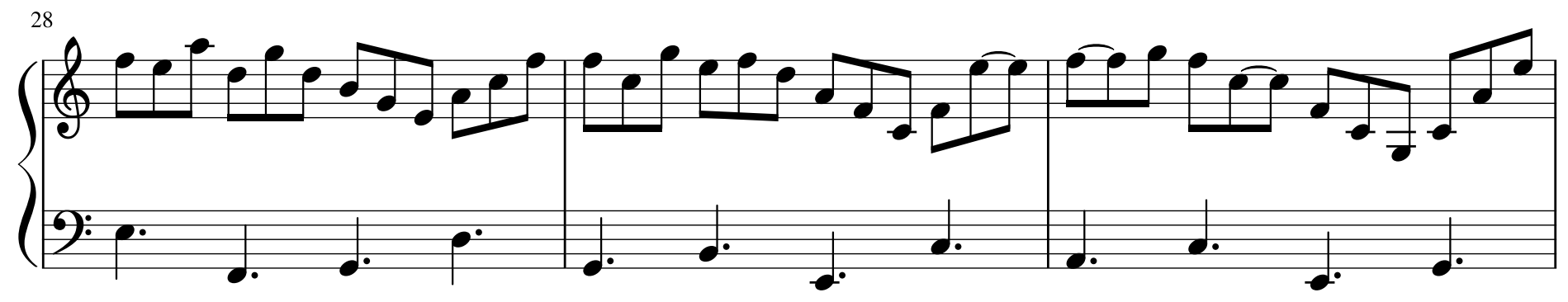

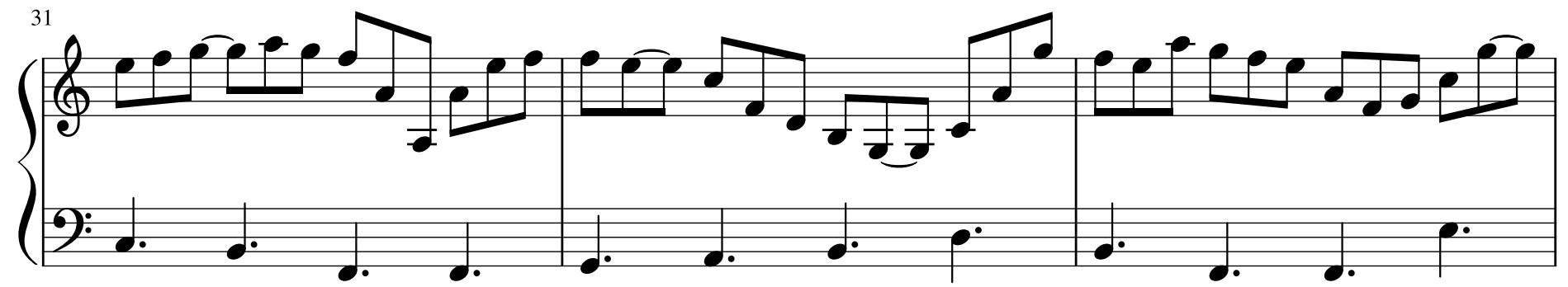




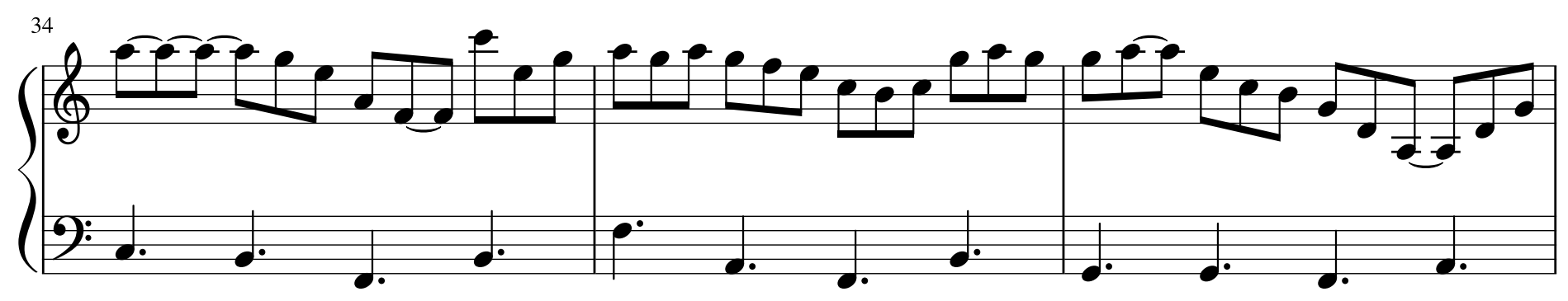

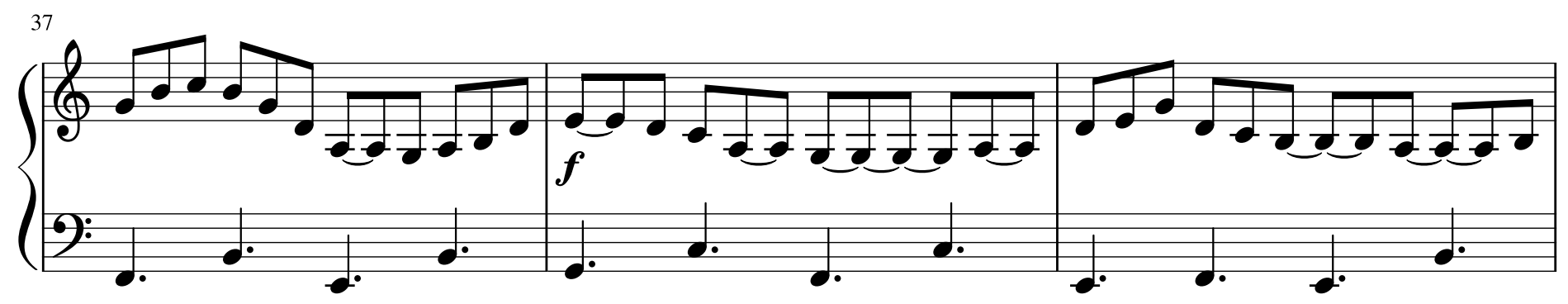

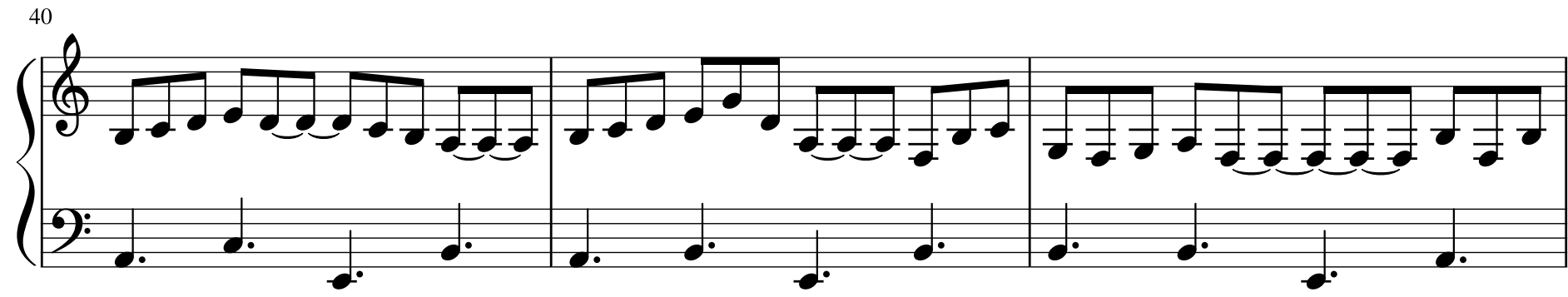

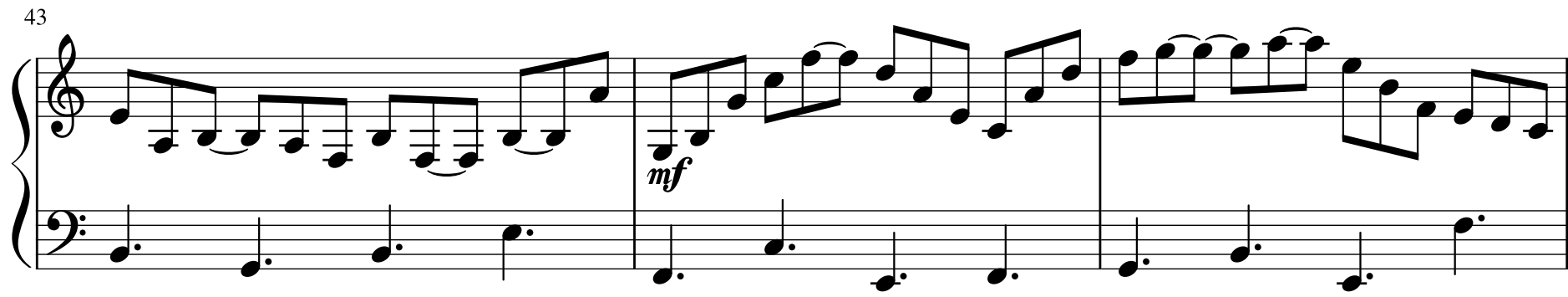

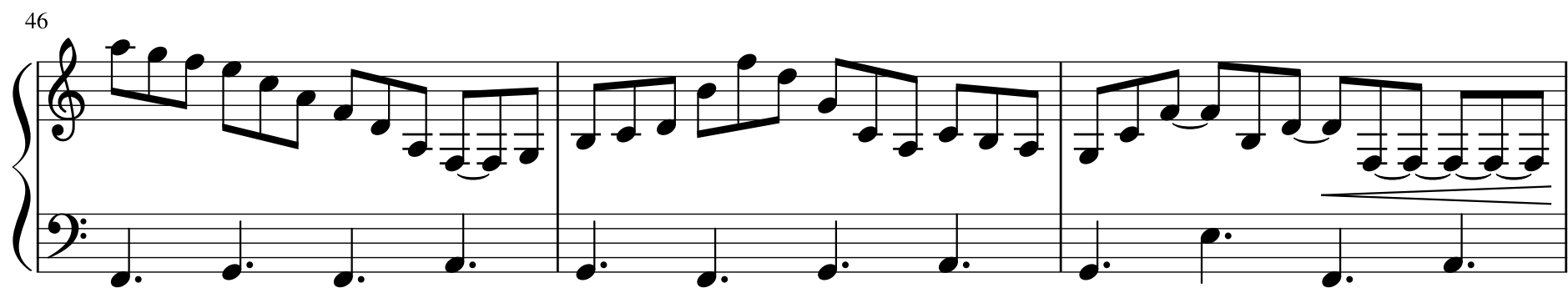

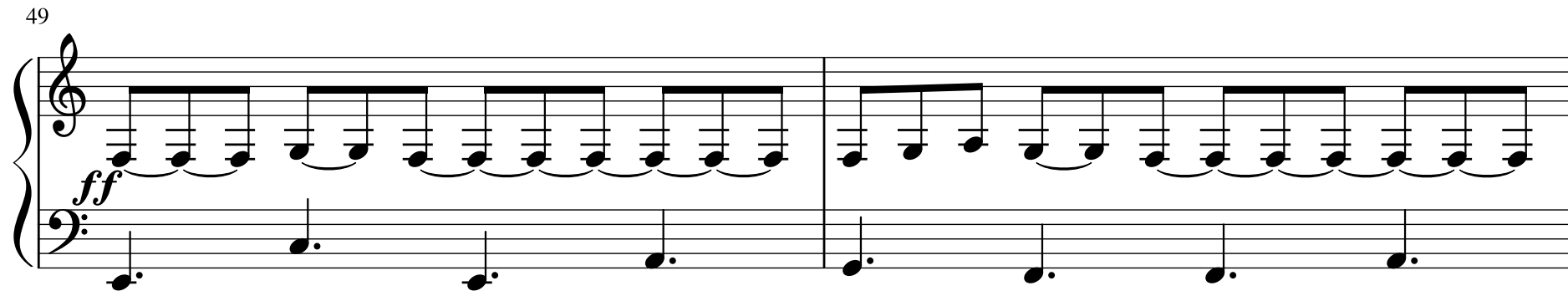




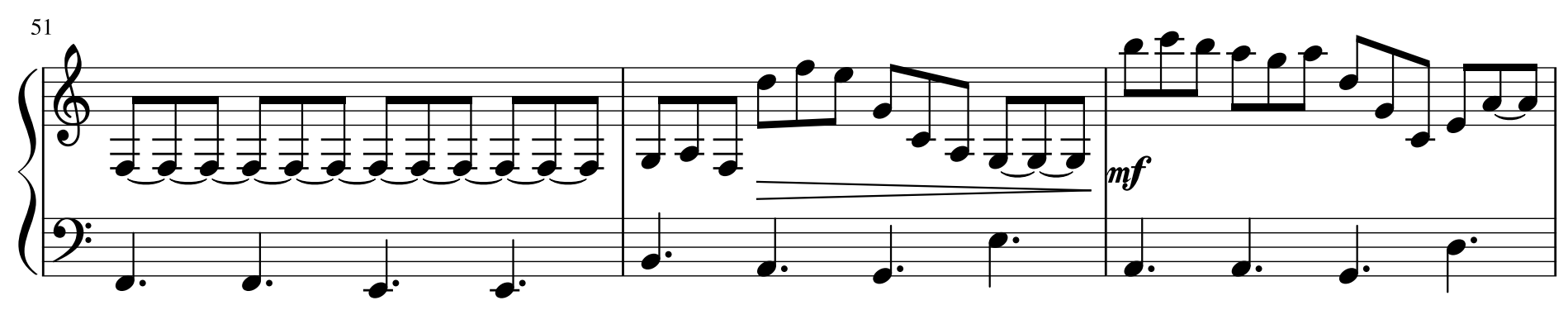

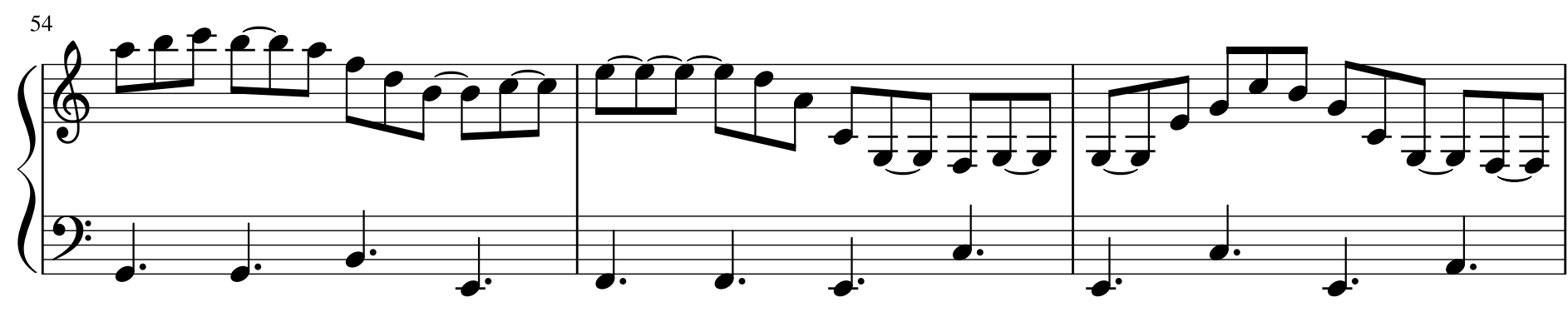

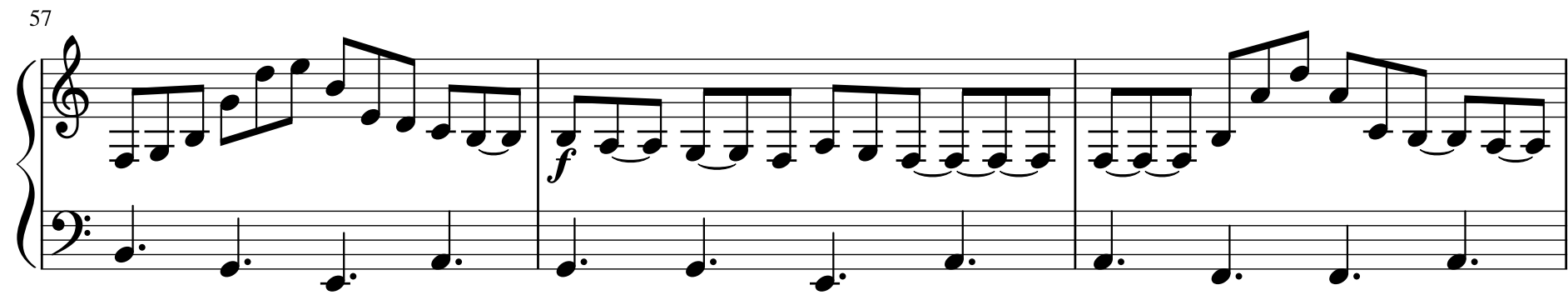

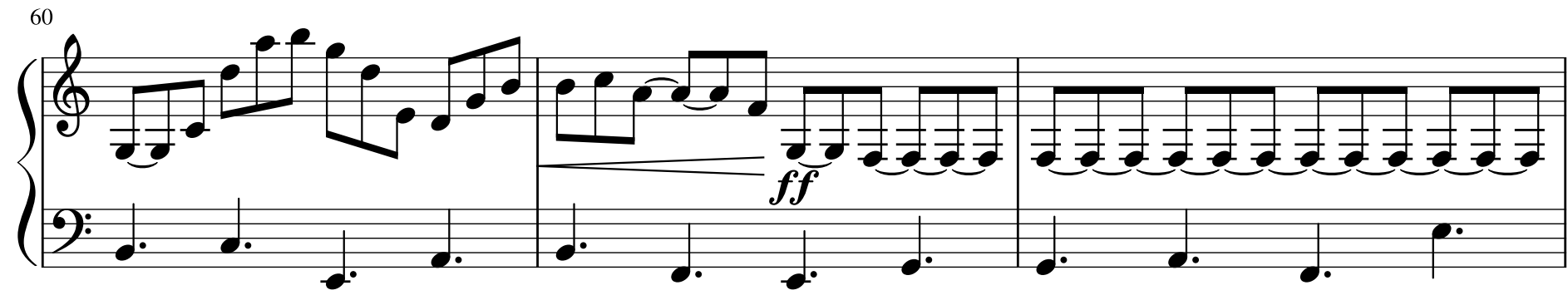

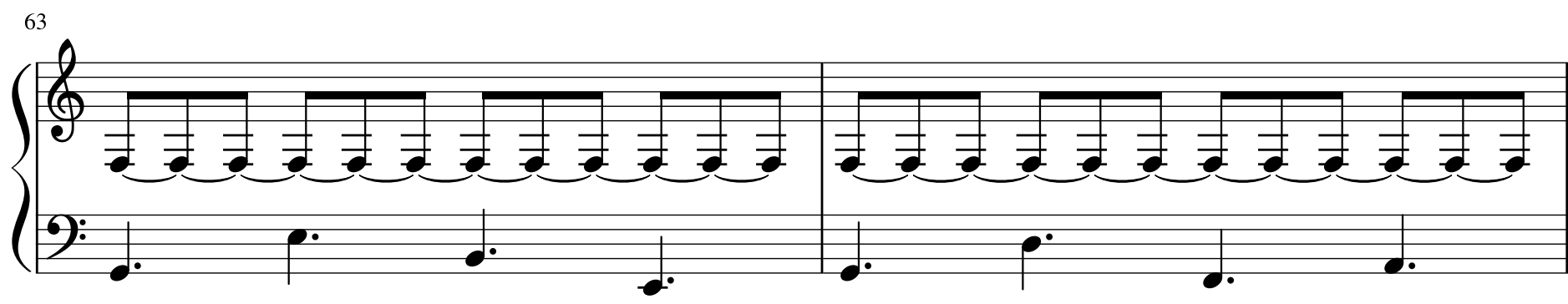

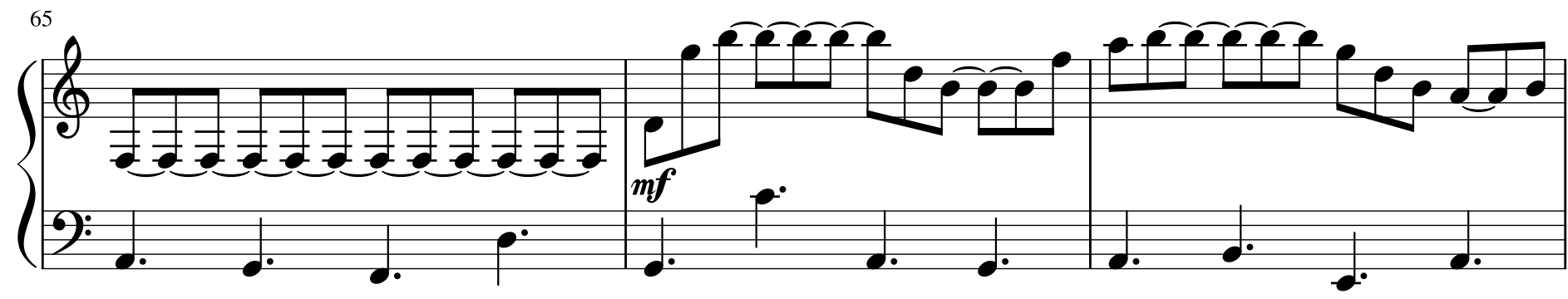



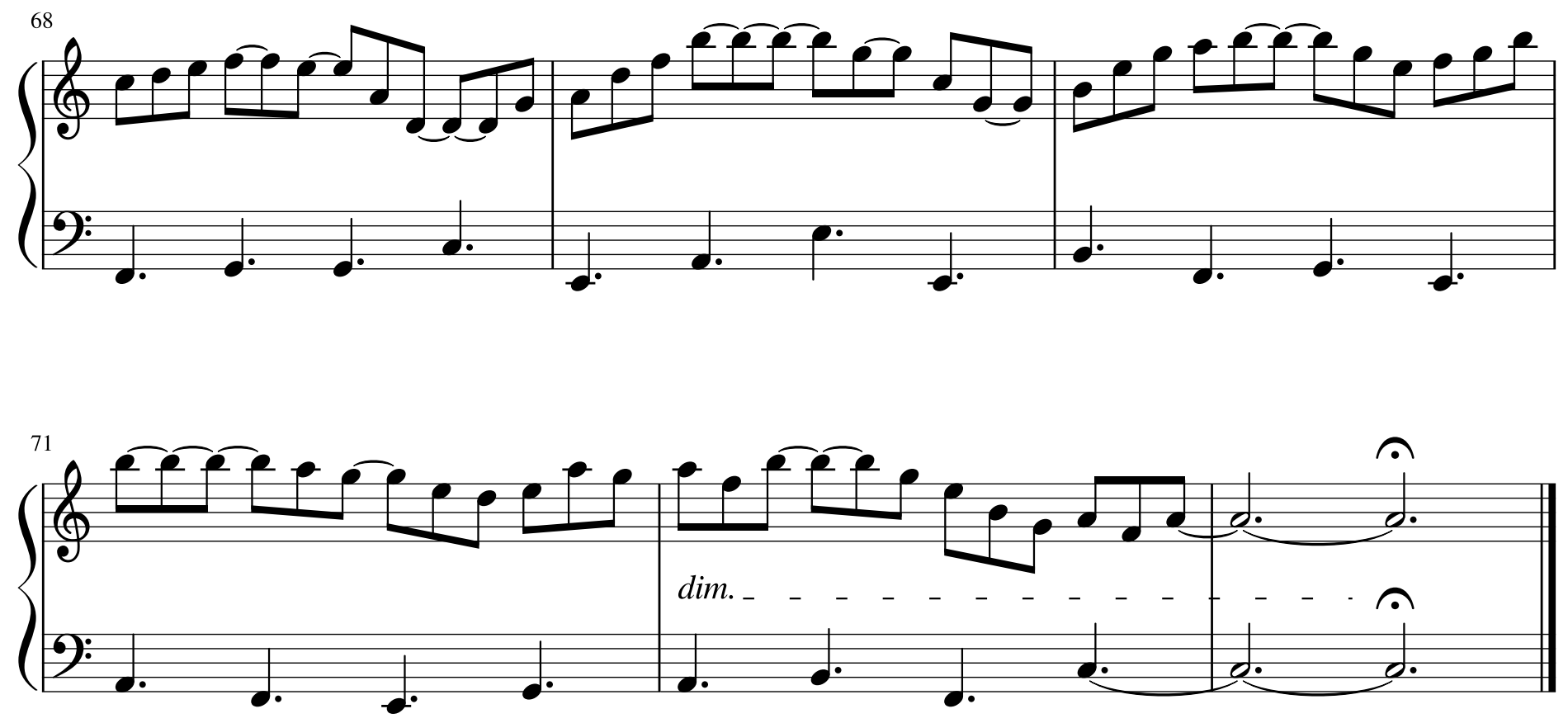
Appendix 2. Audio file (in Ogg Vorbis Audio format) of "The Lament of Las Tablas de Daimiel"

Please click here to download file 'appendix2.ogg'. 